\title{
New record of Thecacineta calix (Ciliophora, Suctorea) from Florida coast, Gulf of Mexico
}

\author{
BABAN INGOLE, ${ }^{1}$ BisWAJIT CHAKRABORTY, ${ }^{2}$ TAPAS CHATTERJEE, ${ }^{3}$ \\ IGOR DOVGAL ${ }^{4}$ \\ ${ }^{1}$ CSIR - National Institute of Oceanography, Dona Paula, Goa-403004, India, ORCID: 0000-0001-6096-6980 \\ ${ }^{2}$ CSIR - National Institute of Oceanography, Dona Paula, Goa-403004, India \\ ${ }^{3}$ Near Harimandir Road, Dhanbad 826001, Jharkhand, India, ORCID: 0000-0001-5532-2726 \\ ${ }^{4}$ A.O. Kovalevsky Institute of Biology of the Southern Seas of RAS, Sevastopol, Russia, ORCID: /0000-0002-3876-233X \\ Corresponding author email: baban.ingole@gmail.com
}

Keywords Ciliate, Thecacineta calix, distribution, harpacticoid copepod, Florida, USA

Summary The suctorian ciliate Thecacineta calix is reported off the coast of Panama, Florida (USA) epibiont on meiobenthic harpacticoid copepod. This is the first report of T. calix from Florida coast. The length of stalk in the present specimens, epibiont on harpacticoids, ranged from one seventh to one eighth of the lorica length.

\section{Nowe stwierdzenie Thecacineta calix (Ciliophora,Suctorea) z wybrzeża Florydy, Zatoka Meksykańska}

Słowa kluczowe orzęski, Thecacineta calix, rozmieszczenie, widłonóg z rzędu Harpacticoida, Floryda, USA

Streszczenie Sysydlaczek Thecacineta calix został stwierdzony na wybrzeżu Florydy (USA) jako epibiont na widłonogu z rzędu Harpacticoida. Jest to pierwsze stwierdzenie tego gatunku na wybrzeżu Florydy. Długość nóżki u okazów epibiontów występujących na Herpacticoida, wahała się od jednej siódmej do jednej ósmej długości loriki.

\section{Introduction}

Suctorian ciliate Thecacineta calix (Schröder, 1907), the type species of genus Thecacineta Collin, 1909, was firstly described as epibiont on marine nematodes from Kerguelen Islands, Antarctica (Schröder, 1907). After first description, the species was not observed during a long time. Matthes (1956) was the first after Schröder who found and reinvestigated the T. calix in Rovinj, Croatia, the Adriatic Sea. He described the peculiarities of morphology and reproduction of $T$. calix and some its congeners in details and erected the new suctorian family Thecacinetidae Matthes, 1956 for loricate suctorians with apical bundle of tentacles and vermigemmic budding. 
Detailed remarks on the systematics and nomenclature of this species are provided in Dovgal et al. (2008).

Several recent investigations of suctorian ciliates distribution demonstrated that $T$. calix is wide spread in marine and brackish waters. The species has been reported as an epibiont on nematodes, copepods, and halacarid mites from the Atlantic, Pacific, Antarctic and Indian Oceans, from the intertidal region to the deep sea. Details of distribution and host specificity of this species is given in Chatterjee et al. (2019). However, further findings of thecacinetid suctorians are important to clarify the ecology and distribution of sessile ciliates.

This paper reports the epibiont Thecacineta calix collected off Panama city, Florida, USA (Gulf of Mexico).

\section{Material and Methods}

Specimens of suctorian ciliate Thecacineta calix, epibiont on meiobenthic harpacticoid copepods were collected off Panama City, Florida (USA), in Gulf of Mexico (Latitude: 30.063N, Longitude: 85.695W) (Figure 1), at $22 \mathrm{~m}$ water depth. Sediment samples were collected by 1 st and $2^{\text {nd }}$ authors (Baban Ingole and Biswajit Chakraborty), using Vibro Corer operated on a Research Vessel: MV Sharp (USA) in a joint expedition as a part of "Multi-Institutional shallow water experiment (GulfEx11) off Panama City, Florida (USA), in Gulf of Mexico" on 11 April 2011.

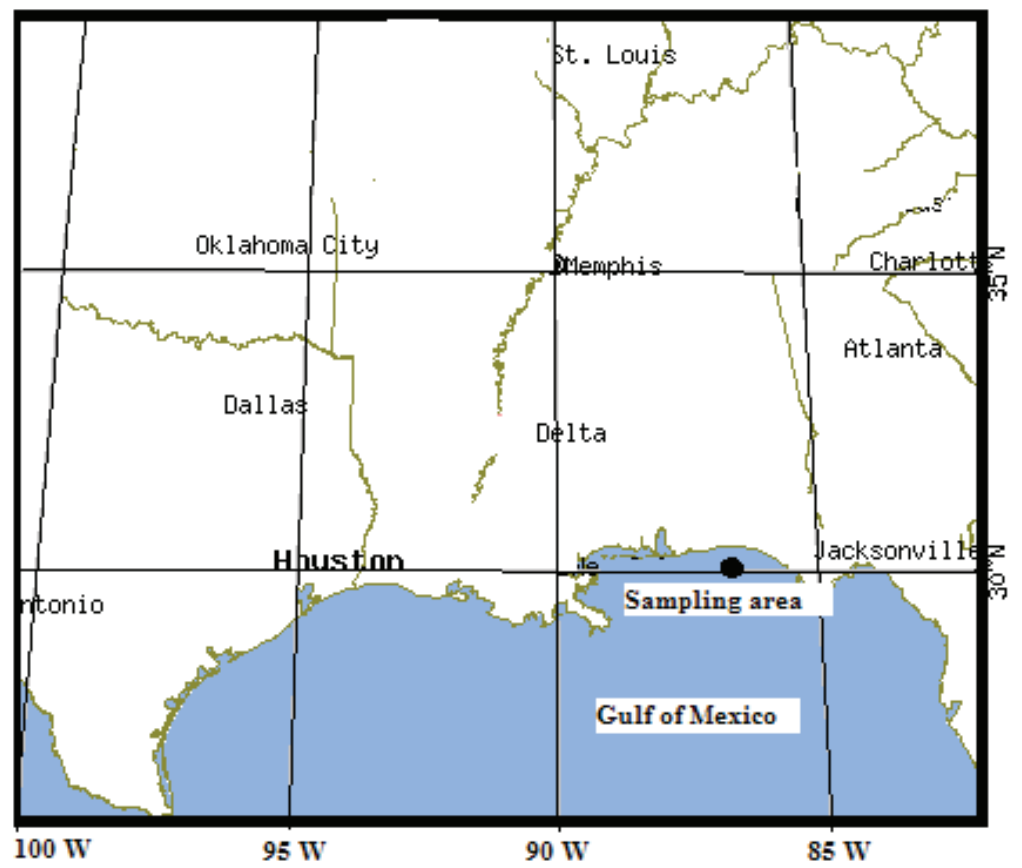

Figure 1. Map of sampling area 
Meiobenthic samples were initially fixed in formalin Rosebengal and latter sieved in the laboratory using a $45 \mu \mathrm{m}$ mesh size sieve. Infested meiofauna were hand sorted, mounted on a $50 \%$ glycerine slide and sealed with DPX.

Measurements were carried out on six specimens using the program Toup View 3.7 for digital camera.

Specimens are kept in the collection of the first author (BI).

\section{Results}

Class Suctorea Claparéde \& Lachmann, 1859

Subclass Exogenia Collin, 1912

Order Vermigemmida Jankowski, 1973

Family Thecacinetidae Matthes, 1956

Genus Thecacineta Collin, 1909

Thecacineta calix (Schröder, 1907) (Figures 2 and 3)

(for synonyms see Chatterjee et al., 2019)

Diagnosis: Marine loricate suctorian. Cell body entirely fills the lorica and attach to its base. Loricais ribbed with a series of transverse annular ridges that become progressively closer toward the base. Apical part of body protrudes beyond lorica aperture. Clavate tentacles (up to 30) arise from apical surface of body. Curved stalk with apical widening. The macronucleus ovoid and located in the basal region of the cell body. Large contractile vacuole located usually near macronucleus in the basal region of body.

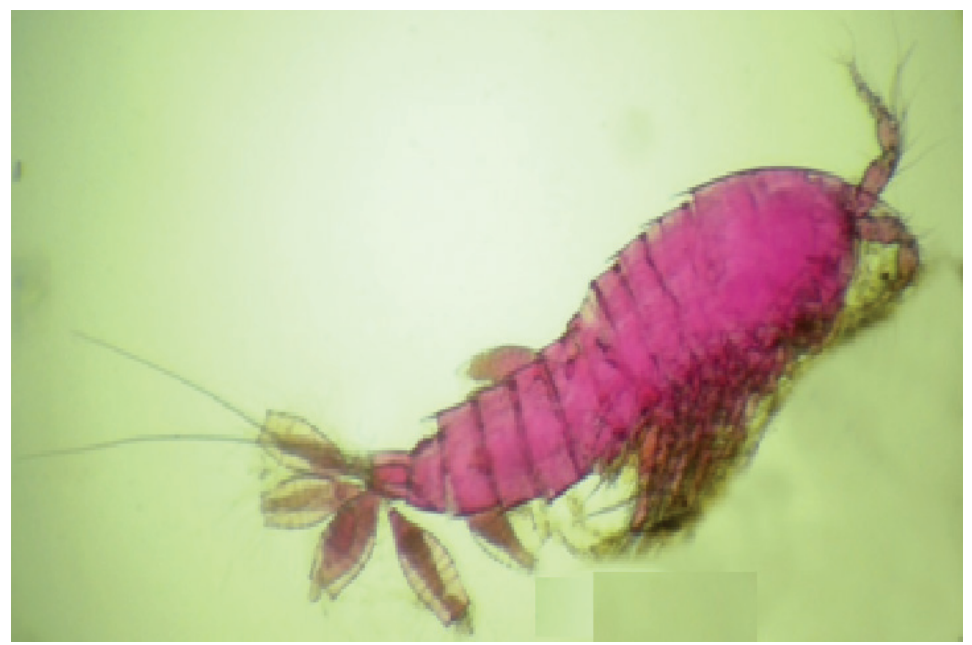

Figure 2. Epibiont Thecacineta calix at host (harpacticoid copepod) body 


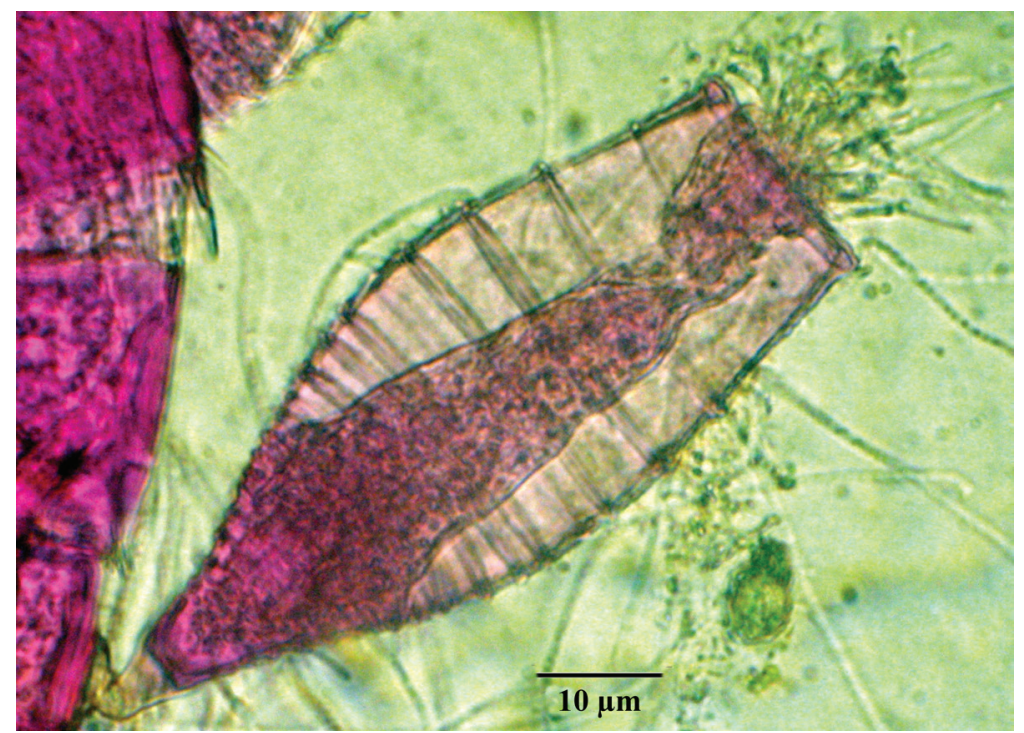

Figure 3. The Thecacineta calix from Florida coast, Gulf of Mexico

Morphometric measurements observed in the present study (Six individuals were measured): Length of lorica: 56-63 $\mu \mathrm{m}$; Maximal width oflorica: 16-26 $\mu \mathrm{m}$; Width of lorica aperture: 12-18 $\mu \mathrm{m}$; Length of body: 63-64 $\mu \mathrm{m}$; Maximal width of body: $12-19 \mu \mathrm{m}$; Stalk length: $8 \mu \mathrm{m}$; Stalk diameter: $4 \mu \mathrm{m}$; Macronucleus diameter: $6-7 \mu \mathrm{m}$; Length of tentacles: $6-19 \mu \mathrm{m}$.

\section{Discussion}

Thecacineta calix has been reported as an epibiont on nematodes, copepods, and halacarid mites from the Atlantic, Pacific, Antarctic and Indian Oceans, from the intertidal region to the deep sea (Chatterjee et al., 2019).

This ciliate species was recorded on harpacticoid copepod from East St. John, U.S. Virgin Islands, $53 \mathrm{~m}$ depth; Caja de Muertos Island near Ponce, Puerto Rico, $52 \mathrm{~m}$ depth; Buoy, La Parguera, Puerto Rico, 46 m depth, Caribbean Sea (Chatterjee et al., 2014); on harpacticoid copepod from Bajo de Sico, a mesophotic reef formation located in Mona Passage of Puerto Rico, $70 \mathrm{~m}$ depth, Caribbean Sea (Chatterjee et al., 2020). It was also reported among algae Enteromorpha flexuosa from Tamiahua lagoon (near Tampache), Veracruz, Mexico (Martínez-Murillo, 1997). This is the first record of this species from the Florida coast.

It should be mentioned that the stalk of T. calix from Florida, epibiont on harpacticoids in present observation is short, the stalk length ranged from one seventh to one eighth of the lorica length. 


\section{Acknowledgements}

First and second author (Baban Ingole, Biswajit Chakraborty) would like to thank Cruise Chief Scientist Dr. John Goff, University of Texas for on board help in sample collection; Dr. Dajun Tang, Dr. D. Jackson and Dr. Kelvin Williams APL University of Washington, Seattle, APL, University of Washington, Seattle for all the necessary logistic and administrative support during the joint GulfeX experiment. Fourth author's (Igor Dovgal) work was made within the framework of research issue of A.O. Kovalevsky Institute of Biology of the Southern Seas of RAS \#AAAA-A19-119060690014-5.

\section{References}

Chatterjee, T., Fernandez-Leborans, G., Schizas, N.V. (2014). Report of Thecacineta calix(Ciliophora: Suctorea) as an epibiont of harpacticoid copepods from Caribbean mesophotic reefs. Caribbean Journal of Science, 48, 44-48.

Chatterjee, T., Nanajkar, M., Dovgal, I., Sergeeva, N., Bhave, S. (2019). New records of epibiont Thecacineta calix (Ciliophora, Suctorea) from the Caspian Sea and Angira Bank, Arabian Sea. Cahiers De Biologie Marine, 60, 445-451.

Chatterjee, T., Dovgal, I., Schizas, N.V. (2020). Report of epibiont ciliates (Ciliophora) on harpacticoid copepods from Caribbean mesophotic reefs. Cahiers De Biologie Marine, 61(1), 13-36.

Dovgal, I., Chatterjee, T., Ingole, B. (2008). Suctorian ciliates (Ciliophora, Suctorea) as epibionts of halacarid mites (Acari: Halacaridae): an overview. Zootaxa, 1810, 60-68.

Martinez-Murillo, M.E. (1997). Ciliados asociados a la vegetacion sumergida y a las raices de mangle en la Laguna de Tamiahua, Veracruz, México. - Ph. D. Thesis. Facultad de Ciencias, Universidad Nacional Autonoma de México.

Matthes, D. (1956).Suktorien studien VIII. Thecacineta calix (Schroder, 1907) (Thecacinetidae nov. fam.) und ihre Fortpflanzung durch Vermoid-Schwarmer. Archiv für Protistenkunde, 101, 477-528.

Schröder, O. (1907). Die Infusorien der Deutschen Sudpolar- Expedition 1901-1903. Deutschen SudpolarExpedition 1901-1903, 9, 349-360.

Cite as: Ingole, B., Chakraborty, B., Chatterjee, T., Dovgal, I. (2020). New record of Thecacineta calix (Ciliophora, Suctorea) from Florida coast, Gulf of Mexico. Acta Biologica, 27, 143-147. DOI: 10.18276/ ab.2020.27-13. 